\title{
Evaluation of the Clinical Success of Implant - Supported Restorations- A Retrospective Study with at Least Two Years of Follow-up Implant Destekli Restorasyonların Klinik Başarısının Değerlendirilmesi: En Az Iki Yıllık Takip ile Restrospektif Çalışma \\ (1) Gamze Paken ${ }^{1}$, (1) Cansu Gül Koca ${ }^{2}$, (1) Merve Ünal ${ }^{1}$ \\ ${ }^{1}$ Uşak University Faculty of Dentistry, Department of Prosthodontics, Uşak, Turkey \\ ${ }^{2}$ Uşak University Faculty of Dentistry, Department of Oral and Maxillofacial Surgery, Uşak, Turkey
}

Keywords

Marginal bone loss, prosthetic rehabilitation, soft tissue-implant interactions

\section{Anahtar Kelimeler \\ Marjinal kemik kaybı, protetik rehabilitasyon, yumuşak doku-implant etkileşimleri}

Received/Geliş Tarihi : 02.11.2020

Accepted/Kabul Tarihi : 01.02.2021

doi:10.4274/meandros.galenos.2021.56688

Address for Correspondence/Yazışma Adresi: Gamze Paken MD,

Uşak University Faculty of Dentistry, Department of Prosthodontics, Uşak, Turkey Phone : +90 5320678048

E-mail :dt.gamzeozturk@gmail.com ORCID ID: orcid.org/0000-0001-5978-395X

(C) Meandros Medical and Dental Journal, Published by Galenos Publishing House.

This is article distributed under the terms of the Creative Commons Attribution NonCommercial 4.0 International Licence (CC BY-NC 4.0).

\begin{abstract}
Objective: This retrospective clinical study aimed to investigate the long-term clinical success of dental implants restored with splinted or non-splinted posterior prostheses with different retention systems.

Materials and Methods: Fifty patients who had undergone dental implant surgery and prosthesis treatment and had a follow-up period of at least 2 years were included in this study. Marginal bone loss was measured from the surrounding bone levels on the mesial and distal surfaces of the implants using a millimetre ruler on panoramic radiographs. The plaque index $(\mathrm{PI})$, gingival index $(\mathrm{GI})$ and bleeding on probing (BOP) were also measured. The Mann-Whitney $\mathrm{U}$ test and ANOVA test were used for statistical analysis.

Results: The mean values of mesial and distal bone loss were $0.72 \pm 0.81$ and $0.62 \pm 0.58$, respectively. The correlation coefficient between mesial and distal bone loss was 0.431 ; thus, a significant difference was found $(p<0.05)$. A significant relationship was found between the $\mathrm{GI}(\mathrm{p}=0.004)$ and $\mathrm{PI}(\mathrm{p}=0.000)$ of dental implants with different retention types. No significant relationship was observed between BOP and retention type ( $p>0.05)$.

Conclusion: Clinically, given the long-term maintenance of soft and hard tissue health, successful results can be achieved with a two-member fixed prosthetic rehabilitation plan on two implants.
\end{abstract}

Öz

Amaç: $\mathrm{Bu}$ retrospektif klinik çalışma, posterior bölgedeki farklı retansiyon sistemlerine sahip splintli veya tek başına planlanan protetik tedavinin dental implantların uzun vadeli klinik başarısına etkisini değerlendirmektedir.

Gereç ve Yöntemler: Çalışmaya, dental implant cerrahisi ve sonrasında protetik tedavi uygulanan ve en az iki yıllık takip süresi olan 50 hasta dahil edildi. Marjinal kemik kaybı, panoramik radyografiler üzerinde milimetrik bir cetvel kullanılarak implantların mezial ve distal yüzeylerini çevreleyen kemik seviyeleri göz önüne 
alınarak değerlendirildi. Ayrıca plak indeksi (PI), diş eti indeksi (GI) ve sondalama sırasında kanama (BOP) değerleri kaydedildi. İstatistiksel analiz için Mann-Whitney U testi ve ANOVA testi kullanıldı.

Bulgular: Mezial ve distal kemik kaybı ortalamaları sırasıyla $0,72 \pm 0,81$ ve $0,62 \pm 0,58$ bulundu. Mezial ve distal kemik kaybı arasındaki korelasyon katsayısı 0,431 olduğu için istatistiksel olarak anlamlı bir fark olduğu sonucuna varıldı $(p<0,05)$ Farklı retansiyon tiplerine sahip diş implantlarının $\mathrm{GI}(p=0,004)$ ve PI $(p=0,000)$ değerleri arasında istatistiksel olarak anlamlı bir ilişki bulundu, fakat BOP ile retansiyon tipi arasında istatistiksel olarak anlamlı bir ilişki olmadığı görüldü $(p>0,05)$.

Sonuç: Klinik olarak, yumuşak ve sert doku sağığının uzun süreli idamesi göz önüne alındığında iki implant üzerine planlanan iki üyeli sabit protetik rehabilitasyon ile başarılı sonuçların elde edilebileceği düşünülmektedir.

\section{Introduction}

Dental implants are the preferred treatment method for the rehabilitation of missing teeth because of their predictable results and high survival and success rates. To achieve predictable long-term results and obtain a favorable prognosis, the number and position of the implants, intermaxillary distance, and quality and quantity of alveolar bone should be comprehensively evaluated before implant surgery (1). Dental implants have several advantages, including a long-term success rate of up to $97 \%$, reduced risk of caries and endodontic problems of corresponding teeth, and preservation of bone in the edentulous site, compared with conventional prostheses (2).

Successful implant treatment results depend on the continuity of the volume and quality of the bone surrounding the implant. Although the diseases that occur in the tissues around dental implants and natural teeth show many common clinical features, the significant structural differences between them are clearly obvious, especially in relation to the surrounding tissues and biological attachment (3). The most important difference is the absence of cement and periodontal ligament around the dental implant, which can limit bacterial penetration. There are also differences in the connection between the tooth and the dental implant with alveolar bone. While there is a direct structural and functional connection between the dental implant and alveolar bone defined as osseointegration, natural teeth also attach to the alveolar bone through Sharpey fibers and the periodontal ligament (4).

Implant-supported superstructures can be fixed using two methods: Cement-retained and screwretained. Both methods can be performed for single, multiple, and full-arch fixed dental prostheses, and both have pros and cons. The screw-retained type has predictable retrievability and easier maintenance, but the screw hole can cause esthetic and occlusal problems. As for the cement-retained type, although it is easy to achieve passivity of fit and provide occlusion control, leaving excess cement is the principal reason for peri-implant tissue disease. The choice of retention type can affect the survival rate of dental implant treatment and influence the development of complications (1). Therefore, it is the clinician's responsibility rather than scientific research to decide on the most suitable retention system. Both systems are subject to technical and biologic complications (57). Biologic complications include peri-implant disease, crestal bone loss, and implant failure. Adequate clinical and radiographic examination methods are required to detect these complications $(3,7)$. Dental radiographs are commonly used before treatment (in the diagnosis and planning of implant surgery) and after treatment (in assessing the adaptation of prosthetic restorations and detecting bone loss).

Peri-implant diseases are classified as peri-implant mucositis and peri-implantitis. Peri-implant mucositis is defined as peri-implant soft tissue inflammation characterized by redness, swelling, and short-term bleeding without bone loss (8). Peri-implantitis is described as a plaque-related pathological condition characterized by inflammation in the surrounding mucosa of the dental implant and progressive bone loss around the implant. Peri-implantitis shows signs of clinical inflammation, such as bleeding or exudation, increased probe depth, and increased resorption of peri-implant bone compared with previous radiographs (9).

Various studies have proved that the retention type of implant prosthesis has an important effect on the incidence of peri-implantitis (10-12). Physicians should develop a plan to predict potential periimplant diseases, evaluate risk factors, and consider alternative treatment methods. They should also have comprehensive knowledge of overall treatment 
options. In the current study, the long-term success and periodontal health of dental implants restored with splinted or non-splinted posterior prostheses and different retention systems with at least two years of follow-up were investigated.

\section{Materials and Methods}

This retrospective clinical study was carried out at Uşak University with ethical committee approval number 41-11-20 (date: 22.07.2020). The protocol of the study was conducted according to the principles described in the Declaration of Helsinki, including all changes and revisions. A total of 50 patients, including 28 males and 22 females, who had previously undergone dental implant surgery and prosthesis treatment at Uşak University Faculty of Dentistry from 2016 to 2020 and attended regular follow-up appointments for at least two years were included. All patients were informed and included in the study after obtaining their consent.

The patients were systemically healthy but partially edentulous in the posterior region. Patients were excluded from the study in case of implant treatment failure, parafunctional habits, signs of wear on the occlusal surface of the teeth, or failure to attend follow-up appointments. Radiographs were taken immediately after prosthetic treatment and at annual controls. Marginal bone loss was measured from the surrounding bone levels on the mesial and distal surfaces of the implants using a millimeter ruler in the instruments section of the radiographic imaging application (PCH-2500 Digital X-Ray Imaging System, PaX-i, VATECH, Hwaseong-si, Korea). To provide calibration, the margin of error was calculated by comparing the implant length in the image with the accurate implant size. The calibration process allowed for more definitive results and standardization of radiographic measurements. The difference between measurements in after-loading and control radiographs was recorded while considering bone loss. When there was more than one image in the region where the implant was in contact with the crest, the most apical contact point was evaluated.

In addition to bone loss measurements from each patient's control radiographs, six points of plaque index (PI) (13), gingival index (GI) (14), and bleeding on probing $(\mathrm{BOP})$ were measured from the surrounding region of the implants to evaluate clinical success. The bleeding values in pocket depth and probing were measured and recorded by taking the average of the obtained data. By comparing the number of members and the type of retention, the relationship between bone loss and periodontal health was investigated.

\section{Statistical Analysis}

Statistical analysis was performed using the IBM SPSS version 25.0 (IBM Corp., NY, USA) program. The normality assumption was checked using the ShapiroWilk test as the first step of data analysis. The MannWhitney $U$ test was applied to examine the difference between the two groups without a normal distribution and independently. The ANOVA test was conducted to examine the difference between the means of variables with more than two independent groups with a normal distribution. The Kruskal-Wallis test was used to examine the difference in the averages of variables with more than two independent groups that did not have a normal distribution. In the analysis of categorical variables, Fisher's Exact test was used in cases in which the assumption of sample size was not provided. The relationship between continuous data without a normal distribution was tested using Spearman's correlation. The G* Power 3.1.9.2 program was used to calculate the adequacy of the sample size at a $95 \%$ confidence level. The level of statistical significance was set to $p<0.05$.

\section{Results}

The mean follow-up duration of the patients was 3.4 years. The distribution of the participants according to their demographic characteristics is shown in Table 1. According to gender, $44.0 \%$ of the patients were female and $56.0 \%$ were male (Table 1 ). The distribution

\begin{tabular}{|l|l|l|l|}
\hline \multicolumn{3}{|l|}{$\begin{array}{l}\text { Table 1. Distribution of people participating in the } \\
\text { research according to demographic features }\end{array}$} \\
$\begin{array}{l}\text { Demographic } \\
\text { features }\end{array}$ & $\mathbf{n}$ & $\%$ \\
\hline \multirow{3}{*}{ Gender } & Female & 22 & 44.0 \\
\cline { 2 - 4 } & Male & 28 & 56.0 \\
\hline \multirow{4}{*}{ Age } & 31 year and younger & 3 & 6.0 \\
\cline { 2 - 4 } & $32-43$ & 14 & 28.0 \\
\cline { 2 - 4 } & $44-55$ & 13 & 26.0 \\
\cline { 2 - 4 } & 56 year and older & 20 & 40.0 \\
\hline
\end{tabular}


of dental implants according to retention type and number of units is shown in Table 2. The averages of mesial $(0.72 \pm 0.81)$ and distal $(0.62 \pm 0.58)$ bone loss are shown in Table 3. The correlation coefficient between mesial and distal bone loss was found to be 0.431 , with $p=0.000$ lower than the alpha value
(0.05), and thus a statistically significant difference was determined (Table 4).

A statistically significant difference was found between the mesial and distal bone loss of single and splinted two-unit and three-unit prosthetic superstructures $(p=0.043)$. However, there was no

\section{Table 2. Distribution of dental implants examined by cementation and number of members}

\begin{tabular}{|l|l|l|l|}
\hline \multirow{5}{*}{ Total dental implants } & & $\mathbf{n}$ & $\mathbf{\%}$ \\
\hline \multirow{4}{*}{ Cementation and number of units } & Single cement & 19 & 16.0 \\
\cline { 2 - 4 } & Single screw-retained & 12 & 10.1 \\
\cline { 2 - 4 } & 2-Unit cement & 24 & 20.2 \\
\cline { 2 - 4 } & 2-Unit screw-retained & 16 & 13.4 \\
\cline { 2 - 4 } Cementation & 3-Unit cement & 26 & 21.9 \\
\cline { 2 - 4 } & 3-Unit screw-retained & 22 & 18.4 \\
\hline \multirow{3}{*}{ Number of units } & Cement & 69 & 58.0 \\
\cline { 2 - 4 } & Screw-retained & 50 & 42.0 \\
\hline & Single & 31 & 26.1 \\
\cline { 2 - 4 } & 2-Units & 40 & 33.6 \\
\cline { 2 - 4 } & 3-Units & 48 & 40.3 \\
\hline
\end{tabular}

Table 3. Mesial and distal bone loss averages and standard deviations

\begin{tabular}{|l|l|l|l|l|l|}
\hline Total dental implants & $\mathbf{n}$ & Minimum & Maximum & $\overline{\mathbf{x}}$ & SD \\
\hline Mesial bone loss & 119 & 0.00 & 4.10 & 0.7271 & 0.81083 \\
\hline Distal bone loss & 119 & 0.00 & 2.42 & 0.6246 & 0.58113 \\
\hline SD: Standard deviation & \multicolumn{5}{l}{} \\
\hline
\end{tabular}

Table 4. The relationship between mesial bone loss and distal bone loss

\begin{tabular}{|l|l|l|}
\hline \multirow{2}{*}{} & Distal bone loss & $\mathbf{p}$ \\
\cline { 2 - 3 } & Rho & $0.000^{*}$ \\
\hline Mesial bone loss & 0.431 & \\
\hline${ }^{p}<0.05$ & & \\
\hline
\end{tabular}

Table 5. Comparison of mesial and distal bone loss averages according to cementation and number of units

\begin{tabular}{|c|c|c|c|c|c|c|c|c|c|c|}
\hline & \multicolumn{5}{|c|}{ Mesial bone loss } & \multicolumn{5}{|c|}{ Distal bone loss } \\
\hline & \multicolumn{2}{|c|}{ Cementation } & \multicolumn{3}{|c|}{ Number of units } & \multicolumn{2}{|c|}{ Cementation } & \multicolumn{3}{|c|}{ Number of units } \\
\hline & Cement & $\begin{array}{l}\text { Screw- } \\
\text { retained }\end{array}$ & Single & 2-Unit & 3-Unit & Cement & $\begin{array}{l}\text { Screw- } \\
\text { retained }\end{array}$ & Single & 2-Unit & 3-Unit \\
\hline $\mathrm{n}$ & 69 & 50 & 31 & 40 & 48 & 69 & 50 & 31 & 32 & 44 \\
\hline $\bar{x}$ & 0.7350 & 0.7163 & 0.7519 & 0.5751 & 0.8378 & 0.6712 & 0.5602 & 0.6920 & 0.4268 & 0.7458 \\
\hline SD & 0.81793 & 0.80909 & 0.98836 & 0.56414 & 0.85466 & 0.57385 & 0.59074 & 0.55577 & 0.41628 & 0.67499 \\
\hline Mean rank & 59.93 & 60.09 & 56.24 & 56.91 & 65.00 & 63.56 & 55.09 & 65.71 & 48.85 & 65.60 \\
\hline$*_{p}$ & \multicolumn{2}{|l|}{0.981} & \multicolumn{3}{|l|}{0.428} & \multicolumn{2}{|l|}{0.186} & \multicolumn{3}{|l|}{$0.043^{*}$} \\
\hline
\end{tabular}


statistically significant difference between retention type and marginal bone level ( $p>0.05$ ) (Table 5).

A statistically significant relationship was found between the $\mathrm{GI}(p=0.004)$ and PI $(p=0.000)$ of dental implants with different retention types $(p<0.05)$ (Table 6). However, there was no statistically significant relationship between BOP and retention type $(p>0.05)$. The relationship between different prosthetic superstructures was not statistically significant in terms of GI, PI, and BOP ( $p>0.05$ ) (Table 7).

\section{Discussion}

The survival rate of dental implants is a key factor in achieving long-term clinical success in dental implant treatment aimed at esthetic and functional improvement. Oral diagnosis and

\begin{tabular}{|c|c|c|c|c|c|c|c|}
\hline & & \multicolumn{4}{|c|}{ Cementation } & \multirow[b]{3}{*}{ Pearson chi-square } & \multirow[b]{3}{*}{ p* } \\
\hline & & \multicolumn{2}{|c|}{ Cemented } & \multicolumn{2}{|c|}{ Screw-retained } & & \\
\hline & & $n$ & $\%$ & $n$ & $\%$ & & \\
\hline \multirow{4}{*}{ GI score } & 0 & 19 & 39.6 & 29 & 60.4 & \multirow{4}{*}{11.187} & \multirow{4}{*}{$0.004 *$} \\
\hline & 1 & 40 & 70.2 & 17 & 29.8 & & \\
\hline & 2 & 10 & 71.4 & 4 & 28.6 & & \\
\hline & 3 & 0 & 0.0 & 0 & 0.0 & & \\
\hline \multirow{4}{*}{ PI score } & 0 & 19 & 36.5 & 33 & 63.5 & \multirow{4}{*}{17.447} & \multirow{4}{*}{$0.000^{*}$} \\
\hline & 1 & 39 & 75.0 & 13 & 25.0 & & \\
\hline & 2 & 11 & 73.3 & 4 & 26.7 & & \\
\hline & 3 & 0 & 0.0 & 0 & 0.0 & & \\
\hline \multirow{2}{*}{ BOP } & + & 58 & 55.8 & 46 & 44.2 & \multirow{2}{*}{1.660} & \multirow{2}{*}{0.198} \\
\hline & - & 11 & 73.3 & 4 & 26.7 & & \\
\hline
\end{tabular}

Table 7. Comparison of plaque index, gingival index and bleeding on probing index with different number of units cross chart and Fisher's Exact test results

\begin{tabular}{|c|c|c|c|c|c|c|c|c|c|}
\hline & & \multicolumn{6}{|c|}{ Unit number } & & \\
\hline & & & & & 2 & & 3 & & \\
\hline & & $\mathbf{n}$ & $\%$ & $\mathbf{n}$ & $\%$ & $\mathbf{n}$ & $\%$ & Fisher's Exact test & $p$ \\
\hline & 0 & 11 & 22.9 & 20 & 41.7 & 17 & 35.4 & & \\
\hline $\mathrm{Gl}_{1}$ & 1 & 15 & 26.3 & 18 & 31.6 & 24 & 42.1 & רס8 & 0 \\
\hline | & 2 & 5 & 35.7 & 2 & 14 & 7 & 50.0 & 3.893 & 0.421 \\
\hline & 3 & 0 & 0.0 & 0 & 0.0 & 0 & 0.0 & & \\
\hline & 0 & 11 & 21.2 & 22 & 42.3 & 19 & 36.5 & & \\
\hline וס וס & 1 & 14 & 26.9 & 16 & 30.8 & 22 & 42.3 & & \\
\hline PI & 2 & 6 & 40.0 & 2 & 13.3 & 7 & 46.7 & 5.129 & 0.274 \\
\hline & 3 & 0 & 0.0 & 0 & 0.0 & 0 & 0.0 & & \\
\hline$B \cap P$ & + & 25 & 24.0 & 38 & 36.5 & 41 & 39.4 & 3553 & 0169 \\
\hline BUP & - & 6 & 40.0 & 2 & 13.3 & 7 & 46.7 & 3.553 & 0.169 \\
\hline
\end{tabular}


planning are essential to accomplish desirable dental implant outcomes. A comprehensive preoperative assessment consists of medical history and intraoral and radiographic evaluation. In the examination before implant surgery, width, height, and quality of bone should be evaluated, and the presence of pathology should be investigated. In dental implant treatment, rehabilitation is considered successful if the osseointegration can function properly and physiologically $(15,16)$.

In the present study, the long-term success and periodontal health of single and splinted two-unit and three-unit prosthetic superstructures with different retention systems were investigated.

In the first year, surrounding bone loss of a dental implant after loading of up to $1.0 \mathrm{~mm}$ is expected in the healing process, but radiographic evidence of any additional bone loss suggests peri-implant disease (17). However, during the first year of dental implant rehabilitation, greater bone loss may occur due to the irregular distribution of stress or excessive occlusal force $(18,19)$. The opinion that has been accepted in previous decades is that bone loss around the dental implant greater than $2.0 \mathrm{~mm}$ after the first year of prosthetic loading is a peri-implantitis finding (20).

When the parameters affecting bone loss are examined, implant-abutment connection, retention type, prosthetic treatment plan, and patient habits should be considered (21-24). According to the results of the current study, there is a significant relationship between the prosthetic treatment plan and marginal bone loss $(p=0.043)$. These results are similar to those of a previous study that compared narrow and wide implants and also observed greater bone loss in the distal area with wide implants (22). In terms of prosthetic superstructures, the singleunit prosthesis group had more distal bone loss than the two-unit splinted on two implant prostheses. A significant difference was found in a previous study, but contrary to the current study, the marginal loss was higher in the splinted group than in the single-unit prosthesis (25). Conversely, other researchers found no significant difference $(22,26,27)$. These conflicting results may originate from the implant location in the jaw or prosthetic features. The current study concluded that there was a statistically significant difference between the two-unit and three-unit splinted on two implant prostheses, and the presence of pontic between the two implants increased bone loss in the distal implant. Higher bone loss between the splinted groups may be due to insufficient oral care, especially under pontic, and progressive occlusal force. The effect of meticulous cleaning and hygiene around molars, which are more difficult to reach than anterior teeth, on long-term bone loss should not be ignored $(25,26)$

Although not statistically significant, it is worth mentioning that marginal bone loss was affected by retention type and that there were higher marginal bone loss values in the cemented type. Repeated abutment replacement in the cemented type during the whole prosthetic treatment is considered to break down the integrity of the surrounding periodontal tissue and to rupture the connective tissue, facilitating the penetration of bacteria compared with the screwretained type. These outcomes are consistent with previous studies (28-31).

Bleeding, probing depth (PD), and bone loss values are important for the long-term success of implant treatment (32). There are many studies on the relationship between clinical periodontal status and marginal bone loss $(20,33,34)$. Malmstrom et al. (34) found no significant relationship between bone loss and the $\mathrm{GI}, \mathrm{PI}$, and PD measurements of dental implants of different lengths in the maxilla and mandible. On the contrary, according to the present study, there was a significant difference between $\mathrm{GI}(\mathrm{p}=0.004)$ and PI $(p=0.00)$ in both retention groups. The highest values were recorded around the cemented type compared with the screw-retained type. However, the absence of a significant difference in PD indicates that there was no significant difference in terms of bone loss according to retention type. Biological complications are more common in cemented-type prostheses due to the large quantity of cement remnants present in the peri-implant sulcus after cementation (1012). Similar to the present study, Weber et al. (35) mentioned that during follow-up, cemented-type prostheses always had a greater degree of gingival bleeding and plaque buildup than screw-retainedtype prostheses.

Radiographic and clinical findings of the implants were observed during at least two follow-up appointments, which might explain the high survival rates in the short follow-up period. The short implant 
follow-up time and not utilizing advanced statistical analyses, such as the Kaplan-Meier test, are among the limitations of this study.

\section{Conclusion}

Within the limitations of the study, the following conclusions can be drawn:

1. In all prosthesis planning compared in the study, more bone loss was observed around the distal implant than around the mesial implant.

2. Although it was not statistically significant, cemented-type prostheses had more marginal bone loss than screw-retained-type prostheses due to the repeated disconnections and reconnections of abutments during prosthetic treatment. Perimucositis clinical findings were mostly seen in cemented-type prostheses.

3. The results suggest that the two-unit splinted on two implants can preserve the marginal bone level. The increase in bone loss in the prosthetic superstructure planned with pontic may be due to the fact that oral care cannot be easily maintained there.

\section{Ethics}

Ethics Committee Approval: This retrospective clinical study was carried out at Uşak University with ethical committee approval number 41-11-20 (date: 22.07.2020).

Informed Consent: All patients were informed and included in the study after obtaining their consent.

Peer-review: Externally and internally peerreviewed.

\section{Authorship Contributions}

Concept: G.P., Design: G.P., Supervision: G.P., Materials: G.P., Data Collection or Processing: M.Ü., Analysis or Interpretation: M.Ü., Literature Search: G.P., C.G.K., Critical Review: C.G.K., Writing: G.P., C.G.K., M.Ü.

Conflict of Interest: No conflict of interest was declared by the authors.

Financial Disclosure: The authors declared that this study received no financial support.

\section{References}

1. Carpentieri J, Greenstein G, Cavallaro J. Hierarchy of restorative space required for different types of dental implant prostheses. J Am Dent Assoc 2019; 150: 695-706.

2. Gupta R, Gupta N, Weber KK. Dental Implants. 2020 Aug 11. In: StatPearls [Internet]. Treasure Island (FL): StatPearls Publishing; 2020 Jan.
3. Renvert S, Persson GR, Pirih FQ, Camargo PM. Peri-implant health, peri-implant mucositis, and peri-implantitis: Case definitions and diagnostic considerations. J Periodontol 2018; 89: 304-12.

4. Misch CE. Contemporary Implant Dentistry. St. Louis: Mosby, 2007: 77-9.

5. von Stein-Lausnitz M, Nickenig HJ, Wolfart S, Neumann K, von Stein-Lausnitz A, Spies BC, et al. Survival rates and complication behaviour of tooth implant-supported, fixed dental prostheses: A systematic review and meta-analysis. J Dent 2019; 88: 103167.

6. Gomes GH, Misawa MYO, Fernandes C, Pannuti CM, Saraiva L, Huynh-Ba G, et al. A systematic review and meta-analysis of the survival rate of implants placed in previously failed sites. Braz Oral Res 2018; 32: 27.

7. Berglundh T PL, Klinge B. A systematic review of the incidence of biological and technical complications in implant dentistry reported in prospective longitudinal studies of at least 5 years. J Clin Periodontol 2002; 29: 197-212.

8. Daubert DM, Weinstein BF, Bordin S, Leroux BG, Flemming TF. Prevalence and predictive factors for peri-implant disease and implant failure: a cross-sectional analysis. J Periodontol 2015; 86: 337-47.

9. Berglundh T, Armitage G, Araujo MG, Avila-Ortiz G, Blanco J, Camargo PM, et al. Peri-implant diseases and conditions: Consensus report of workgroup 4 of the 2017 World Workshop on the Classification of Periodontal and Peri-Implant Diseases and Conditions. J Periodontol 2018; 89: 313-8.

10. Jivraj S. Screw versus cemented implant restorations: The decision-making process. J Dent Implant 2018; 8: 9-19.

11. Agar JR, Cameron SM, Hughbanks JC, Parker MH. Cement removal from restorations luted to titanium abutments with simulated subgingival margins. J Prosthet Dent 1997; 78: 43-7.

12. Linkevicius $T$, Vindasiute $E$, Puisys A, Linkeviciene L, Maslova N, Puriene $A$. The influence of the cementation margin position on the amount of undetected cement. A prospective clinical study. Clin Oral Implants Res 2013; 24: 71-6.

13. Silness J, Loe H. Periodontal disease in pregnancy. II. correlation between oral hygiene and periodontal condtion. Acta Odontol Scand 1964; 22: 121-35.

14. Loe $\mathrm{H}$, Silness J. Periodontal disease in pregnancy. I. prevalence and severity. Acta Odontol Scand 1963; 21: 533-51.

15. Goodacre CJ, Bernal G, Rungcharassaeng K, Kan JY. Clinical complications with implants and implant prostheses. J Prosthet Dent 2003; 90: 121-32.

16. Jivraj $\mathrm{S}$, Chee $\mathrm{W}$. Treatment planning of implants in the aesthetic zone. Br Dent J 2006; 201: 77-89.

17. Albrektsson T, Zarb G, Worthington P, Eriksson AR. The longterm efficacy of currently used dental implants: a review and proposed criteria of success. Int J Oral Maxillofac Implants 1986; 1: 11-25.

18. Frost HM. Bone "mass" and the "mechanostat": a proposal. Anat Rec 1987; 219: 1-9.

19. Carter DR, Fyhrie DP, Whalen RT. Trabecular bone density and loading history: regulation of connective tissue biology by mechanical energy. J Biomech 1987; 20: 785-94. 
20. Lee CT, Huang YW, Zhu L, Weltman R. Prevalences of periimplantitis and peri-implant mucositis: systematic review and meta-analysis. J Dent 2017; 62: 1-12.

21. Vélez J, Peláez J, López-Suárez C, Agustín-Panadero R, Tobar C, Suárez MJ. Influence of Implant Connection, Abutment Design and Screw Insertion Torque on Implant-Abutment Misfit. J Clin Med 2020; 9: 2365.

22. Shi JY, Xu FY, Zhuang LF, Gu YX, Qiao SC, Lai HC. Long-term outcomes of narrow diameter implants in posterior jaws: $A$ retrospective study with at least 8-year follow-up. Clin Oral Implants Res 2018; 29: 76-81.

23. Misch CE. Short dental implants: a literature review and rationale for use. Dent Today 2005; 24: 64-6.

24. Mendonça JA, Francischone CE, Senna PM, Matos de Oliveira AE, Sotto-Maior BS. A retrospective evaluation of the survival rates of splinted and non-splinted short dental implants in posterior partially edentulous jaws. J Periodontol 2014; 85: 787-94.

25. Alrabiah M, Al Deeb M, Alsahhaf A, AlFawaz YF, Al-Aali KA, Vohra $F$, et al. Clinical and radiographic assessment of narrow-diameter and regular-diameter implants in the anterior and posterior jaw: 2 to 6 years of follow-up. J Periodontal Implant Sci 2020; 50: 97105.

26. Al-Aali KA, ArRejaie AS, Alrahlah A, AlFawaz YF, Abduljabbar T, Vohra F. Clinical and radiographic peri-implant health status around narrow diameter implant-supported single and splinted crowns. Clin Implant Dent Relat Res 2019; 21: 386-90.

27. Vigolo P, Mutinelli S, Zaccaria M, Stellini E. Clinical evaluation of marginal bone level change around multiple adjacent implants restored with splinted and nonsplinted restorations: a 10-year randomized controlled trial. Int J Oral Maxillofac Implants 2015; 30: $411-8$.
28. Becker K, Mihatovic I, Golubovic V, Schwarz F. Impact of abutment material and dis-/re-connection on soft and hard tissue changes at implants with platform-switching. J Clin Periodontol 2012; 39: 774-80.

29. Canullo L, Bignozzi I, Cocchetto R, Cristalli MP, Iannello G. Immediate positioning of a definitive abutment versus repeated abutment replacements in post-extractive implants: 3-year follow-up of a randomised multicentre clinical trial. Eur J Oral Implantol 2010; 3: 285-96.

30. Iglhaut G, Becker K, Golubovic V, Schliephake H, Mihatovic I. The impact of dis-/reconnection of laser microgrooved and machined implant abutments on soft- and hard-tissue healing. Clin Oral Implants Res 2013; 24: 391-7.

31. Rodríguez $X$, Vela $X$, Méndez $V$, Segalà $M$, Calvo-Guirado JL, Tarnow DP. The effect of abutment dis/reconnections on periimplant bone resorption: a radiologic study of platform-switched and non-platform-switched implants placed in animals. Clin Oral Implants Res 2013; 24: 305-11.

32. Brägger U. Use of radiographs in evaluating success, stability and failure in implant dentistry. Periodontol 2000 1998; 17: 77-88.

33. Albrektsson T, Zarb GA. Current interpretations of the osseointegrated response: clinical significance. Int J Prosthodont 1993; 6: 95-105.

34. Malmstrom H, Gupta B, Ghanem A, Cacciato R, Ren Y, Romanos GE. Success rate of short dental implants supporting single crowns and fixed bridges. Clin Oral Implants Res 2016; 27: $1093-$ 8.

35. Weber HP, Kim DM, Ng MW, Hwang JW, Fiorellini JP. Peri-implant soft-tissue health surrounding cement- and screw-retained implant restorations: a multi-center, 3-year prospective study. Clin Oral Implants Res 2006; 17: 375-9. 